Proceeding of the $2^{\text {nd }}$ International Conference on Agriculture, Food Security and Safety, Vol. 2, 2021, pp. 83-91 Copyright ${ }^{\circ}$ () 2021 iConferences

ISSN 2682-7158

DOI: https://doi.org/10.32789/agrofood.2021.1008

\title{
Agricultural Sustainability through Agritourism in Oman and Potentials for Adoption
}

\author{
Al Hinai $\mathrm{A}^{1}$, Jayasuriya $\mathrm{H}^{2}$ \\ ${ }^{1}$ Doctoral candidate, Department of Soils Water and Agricultural Engineering, College of Agriculture and \\ Marine Sciences, Sultan Qaboos University, Oman, s81455@student.squ.edu.om \\ ${ }^{2}$ Associate Professor, Department of Soils Water and Agricultural Engineering, College of Agriculture and \\ Marine Sciences, Sultan Qaboos University, Oman, hemjay@squ.edu.om
}




\title{
AGRICULTURAL SUSTAINABILITY THROUGH AGRITOURISM IN OMAN AND POTENTIALS FOR ADOPTION
}

\begin{abstract}
Most Middle Eastern countries are geographically located in arid or semi-arid climatic conditions. Agricultural practices have not been impressive in achieving sustainability in these countries. With the changing geopolitical undercurrents, these countries with the GCC countries as part of the Middle East are facing fluctuating economies as the oil price has become fragile and unstable. Oman's economy is heavily depending on hydrocarbons, and looking at other contribution sectors is necessary. The contribution from the agricultural sector is comparatively insignificant, but it explicitly diversified arid cropping systems and unique to the country. The agricultural production activities are often done with unique cultural practices, and this sector can be attractive to tourists. The tourism industry is considered a potential sector for boosting the economy that is aligned with Oman Vision 2040 strategy. This paper aims to investigate the potential of agritourism in different regions in Oman for adoption as a new venture. Different agricultural sites and products for promoting agritourism are selected for the study. The farm characteristic and activities at different agricultural sites are identified. The prediction number of agritourists and the farm income are calculated. The results of this study show that the selected agricultural sites in this study indicated highly potential for agritourism. Salalah is the best agritourism destination with predicated annual agritourists 188,000 and US $\$ 5 \mathrm{~m}$ of farm income. Agritourism would assist in achieving agricultural sustainability through product value-addition, which would open access to global markets and improve the livelihood of farmers
\end{abstract}

Keywords: Agritourism; arid-climate; economic diversification; farm-characteristics, sustainability; value addition

\section{Introduction}

Most Middle Eastern countries are geographically located in arid or semi-arid climatic conditions (Baumer, 1983; Djuma et al., 2016; Mizyed, 2013). Agricultural practices have not been impressive in achieving sustainability and enhancing food security in these countries (Brief, 2010). With the changing geopolitical undercurrents, these countries are facing fluctuating economies as the oil price has become fragile and unstable. The Gulf Corporation Council (GCC), which is part of the Middle East countries are heavily depending on oil as the first income for the country that leads to a lack of economic diversification (Alqattan \& Alhayky, 2016) which calls for looking at other sustainable sectors that contribute to raising the country's economy

Oman is one of the GCC countries that are heavily dependent on hydrocarbons (oil and gas) that contributed to approximately $90 \%$ of the government revenues in 2020 (CBO, 2017). However, the country's economy has been affected by the fluctuation of oil prices (Kitous et al., 2016). Therefore, the country looks to other non-hydrocarbon sectors that might contribute to economic growth, such as trade, industry, tourism, and agriculture (SARADS, 2016). Oman vision 2040 stated that agricultural and rural development through tourism is playing an important role in economic diversification which makes this diversification, not an option but necessary (Oman Vision 2040, 2020; SARADS, 2016) 
Agritourism is a concept consisting of agriculture and tourism sectors, which contributes to their development and enhances the benefits for both. It is also called farm tourism, which may accelerate its growth in the future (Arroyo et al., 2013; Kumar \& Dubey, 2016). Among the goals that agritourism achieves is to increase the number of tourists and improve the income of many farms through improving various agricultural activities. In different areas of the world, agritourism is considered a dynamic business sector (Sznajder, 2009).

The agritourism concept is very primitive, and week in Oman, perhaps the agriculture and tourism sector are in continuous upward development. Zekri (2011) mentioned that visiting tourists to farms had raised the farm's profits from 6 to $21 \%$, and there could be an additional $10 \%$ increase in the transportation cost. Therefore, this paper aims to investigate the potential of agritourism in different regions in Oman for adoption as a new venture.

\section{Literature Review}

\section{Tourism in Oman}

Abdul-Ghani, (2006) predicted that by the end of 2020, tourism in Oman was expected to contribute about 3\% of the GDP, which would increase tourism revenues by ten times (about US\$ 338 million). Oman vision 2040 aims to develop the tourism sector and its participation in the economic diversification and financial sustainability of the country by increasing the contribution to the GDP from 6-10\% by 2040 (AlMaimani \& Johari, 2014; Oman Vision 2040, 2020). The statistical indicators of tourism growth in Oman from 2011-2017 are shown in Table 1, and the tourism development plan of the Oman vision 2040 is shown in Table 2.

Table 1: Growth rate of the statistical indicators of tourism in Oman from 2011-2017.

\begin{tabular}{|c|c|c|c|c|c|c|c|c|}
\hline Indicator & 2011 & 2012 & 2013 & 2014 & 2105 & 2016 & 2017 & $\begin{array}{l}\text { Growth } \\
\text { rate }(\%)\end{array}$ \\
\hline $\begin{array}{l}\text { Direct added value of the } \\
\text { sector (million US\$) }\end{array}$ & 1353 & 1593 & 1697 & 1792 & 1903 & 1858 & 1893 & 5.7 \\
\hline GDP Contribution (\%) & 1.9 & 2.0 & 2.1 & 2.1 & 2.7 & 2.8 & 2.6 & 5.4 \\
\hline $\begin{array}{l}\text { Number of incoming tourists } \\
\text { (million) }\end{array}$ & 1.4 & 1.7 & 1.9 & 2.2 & 2.6 & 3.2 & 3.3 & 15.2 \\
\hline
\end{tabular}

Source: (Abdul-Ghani, 2006; Al-Badi et al., 2017; UNWTO, 2019)

Table 2: Plan of Oman vision 2040 of tourism development

\begin{tabular}{lc}
\hline Objective & Plan \\
\hline Increase the employment opportunity of the tourism sector & More than $1 / 2$ million \\
\hline Increase the investment volume & US\$ 49 billion \\
\hline Increase the contribution to the GDP & From 6 to $9 \%$ \\
\hline Improve the small and medium institutions & 1100 institutions \\
\hline
\end{tabular}

Source: (Abdul-Ghani, 2006; Al-Badi et al., 2017; UNWTO, 2019). 


\section{Nature Tourism Destinations in Oman}

The natural, heritage and cultural diversity of tourism sites in the Sultanate of Oman distinguished them from many of the neighbouring GCC countries. A variety of terrains extend from the Musandam Governorate in the north, known as the Gulf Gate ending, to the Dhofar Governorate in the south, which is famous for the autumn monsoon winds. Many natural tourism sites in Oman, as shown in Table 3, are located in areas of agricultural activities, which may contribute to creating opportunities for agritourism within the respective regions.

Table 3: Nature tourist destinations in Oman

\begin{tabular}{|c|c|}
\hline Category & Description \\
\hline \multicolumn{2}{|l|}{ Castle and Forts } \\
\hline Bahla Castle & An archaeological sites listed on the UNESCO World List \\
\hline Nizwa Castle & Built in the year $1668 \mathrm{AD}$, circular shape \\
\hline Nakhal Castle & A large castle with hot springs and surrounded by high mountains \\
\hline \multicolumn{2}{|l|}{ Hot Springs } \\
\hline Al-Kasfah Hot Spring & $\begin{array}{c}\text { Spring of natural water, fixed temperature } 45^{\circ} \mathrm{C} \text {. Natural treatment of } \\
\text { rheumatism and skin diseases }\end{array}$ \\
\hline Al-Thowarah Hot Spring & Warm water flows from the valley for a distance of 300 meters \\
\hline \multicolumn{2}{|l|}{ Beaches } \\
\hline $\begin{array}{l}\text { Beach of Musandam } \\
\text { Peninsula }\end{array}$ & Diving and swimming sites, and the small fish village \\
\hline Gulf Coast of Oman & The famous historical district \\
\hline Coast of Dhofar & Long sandy beaches with coconut trees $\&$ rare birds \\
\hline \multicolumn{2}{|l|}{ Mountains } \\
\hline Mount Grand Canyon & Highest mountains in Oman, $3005 \mathrm{~m}$ \\
\hline Al-Jabal Al-Akhdar & Villages and farms on the edge of the slopes, steep valleys, and winding roads \\
\hline
\end{tabular}

Source: (Al-Sheriani, 2014; Anon, 2018, 2019; Nasser, 2017).

\section{Agriculture in Oman}

Agriculture is one of the main sources of life in Omani history, which is considered one of the most important sectors to achieve food security. The contribution of the agricultural sector to the national income is around US\$ 1560 million annually. The total cultivated area is more than 60 thousand hectares with various crops, including fruits, vegetables, fodder, and field crops, as shown in Table 4 (FAO, 2008, 2019; MOI, 2015). Most of the cultivated area is practised in the north-eastern coastal belt of Oman (Al-Ismaili et al., 2017; Jayasuriya et al., 2017). 
Alaa A.H. / Agricultural sustainability through agritourism in oman and potentials for adoption

Table 4: Total area cultivated by different crops

\begin{tabular}{lcc}
\hline Crop & Area (ha) & Total area (\%) \\
\hline Fruit & 39926 & 58.03 \\
\hline Vegetables & 5154 & 8.10 \\
\hline Fodder & 15956 & 25.08 \\
\hline Field crops & 5596 & 8.79 \\
\hline Total & 63632 & 100 \\
\hline
\end{tabular}

Source: (FAO, 2008, 2019; MOI, 2015).

\section{Methodology}

At the beginning of the research, the most important agricultural sites in Oman and the crops available in those sites that can be selected for promoting agritourism were identified, as shown in Table 5.

Table 5: Selected agricultural sites and products for promoting Agritourism.

\begin{tabular}{|c|c|}
\hline Agricultural site & Product \\
\hline Al-Sharkhiya & $\begin{array}{l}\text { Date fruits, traditional crafts (textiles, gold and silver jewellery, leather tanning, } \\
\text { shoemaking) (Omaninfo, 2021) }\end{array}$ \\
\hline Al-Batinah & Wheatfields, Bee's honey, dates, mango, lemon, and others (Suhar-Omania, 2017) \\
\hline Salalah & $\begin{array}{l}\text { Coconut and banana, camel milk and meat, beef and cow milk, and frankincense } \\
\text { (Luban) (Atheer-Omania, 2017) }\end{array}$ \\
\hline Nizwa & $\begin{array}{l}\text { Gold and silver industry, Cooper industry, sugarcane industry, Omani Halwa industry } \\
\text { (Al-Salmi, 2018) }\end{array}$ \\
\hline Bahla & Date palm products (handcraft), dates fruit, sugar cane, pottery (Al-Kharosi, 2017) \\
\hline Al-Jabal Al-Akhdar & Pomegranate, peach, apple, walnut, roses, orchids (Al-Kalbani et al., 2016) \\
\hline Muscat & Omani Halwa, Fruits and vegetables (Al-Kharosi, 2017) \\
\hline
\end{tabular}

After that, the farm characteristics of the selected agricultural sites in Table 5 were identified, and the possibility of practicing various agritourism activities in these farms for tourists is shown in Table 6 .

Table 6: Farm characteristics of different selected regions for applying different agritourism practices.

\begin{tabular}{lcc}
\hline $\begin{array}{l}\text { Agricultural site } \\
\text { Governorate } \\
\text { (region) }\end{array}$ & Farm characteristic & Possible agritourism activities in farms \\
\hline $\begin{array}{l}\text { Al-Sharkhiya } \\
\text { (Bidyyah) }\end{array}$ & Date fruit & $\begin{array}{c}\text { Participating in harvesting, stripping, and cooking processes, } \\
\text { selling date products }\end{array}$ \\
\hline $\begin{array}{l}\text { Al-Batinah } \\
\text { (Barka, Nakhal) }\end{array}$ & $\begin{array}{c}\text { Tomato, cucumber, and } \\
\text { banana }\end{array}$ & $\begin{array}{c}\text { Participating in farm activities and processes (smelling, } \\
\text { touching, picking), selling fresh and other value-added products } \\
\text { (sauces, pickles, etc.) }\end{array}$ \\
\cline { 2 - 3 } & Date fruit & $\begin{array}{c}\text { Participating in date processing activities and selling date } \\
\text { products }\end{array}$ \\
\hline $\begin{array}{l}\text { Dhofar } \\
\text { (Salalah) }\end{array}$ & Coconut and banana & $\begin{array}{c}\text { Participating in farm activities (smelling, touching, picking, } \\
\text { tasting), selling fresh banana and coconut, and other coconut } \\
\text { value-added products (water, oil, etc.) }\end{array}$ \\
\hline
\end{tabular}


Alaa A.H / Agricultural Sustainability through Agritourism in Oman and Potentials for Adoption

\begin{tabular}{lcc}
\hline & Fragrance (Luban) & $\begin{array}{c}\text { Participating in the extraction process of Luban from the tree } \\
\text { trunk, selling Luban products }\end{array}$ \\
\hline $\begin{array}{l}\text { Al-Dhakliyah } \\
\text { (Nizwa, Bahla, Al- } \\
\text { Jabal Al-Akdar) }\end{array}$ & Date fruit & $\begin{array}{c}\text { Participating in the harvesting process, an exhibition showing } \\
\text { the traditional and handicrafts products, selling fresh and value- } \\
\text { added products (paste, syrup, etc.) }\end{array}$ \\
\cline { 2 - 3 } & Sugarcane & $\begin{array}{c}\text { Participating in the extraction process, touching and testing the } \\
\text { products, selling value-added products }\end{array}$ \\
\cline { 2 - 3 } & Pomegranate and rose & $\begin{array}{c}\text { Participating in the picking process, an exhibition showing the } \\
\text { manufacturing process (rose water \& oil), selling the fresh and } \\
\text { value-added products }\end{array}$ \\
\hline
\end{tabular}

The potential farms' incomes are determined by the predicted number of agritourists visiting the agritourism farms, which is determined by assuming $25 \%$ of the total number of the annual tourists visiting the selected agricultural sites in this study. Then, the contribution amount of raising the farm income from each agritourist is estimated at US\$26. Therefore, the number of agritourists is multiplied by US\$26 to get the potential farm income. Zekri (2011) reported a $10 \%$ increase in farm income due to agritourism activities.

\section{Results}

The selected agritourism farms at different agritourism sites have shown high potential for applying agritourism in Oman. The predicted number of agritourists and expected farm income of selected different agricultural sites (as examples) are shown in Table 7.

Table 7: Predicted number of agritourists and expected farm income of the agritourism sites.

\begin{tabular}{|c|c|c|c|c|}
\hline Agritourism sites & Agritourism farm & $\begin{array}{c}\text { Annual tourist } \\
\text { visit/ year }\end{array}$ & $\begin{array}{l}\text { Predicted number of } \\
\text { Agritourists }\end{array}$ & $\begin{array}{l}\text { Potential farm } \\
\text { income (US\$) }\end{array}$ \\
\hline Nizwa & \multirow[t]{4}{*}{ Date fruit } & $101,000 / 2015$ & 25,250 & 656,500 \\
\hline Bahla & & $47,000 / 2015$ & 11,750 & 305,500 \\
\hline Bydiah & & $167,000 / 2015$ & 41,750 & $1,085,500$ \\
\hline Nakhal & & $20,662 / 2017$ & 5,166 & 134,316 \\
\hline Bahla & Sugarcane & $47,000 / 2015$ & 11,750 & 305,500 \\
\hline Al-Jabal Al-Akhdar & $\begin{array}{l}\text { Pomegranate and } \\
\text { roses }\end{array}$ & $226,487 / 2018$ & 56,622 & $1,472,172$ \\
\hline Barka & $\begin{array}{l}\text { Tomato and } \\
\text { cucumber }\end{array}$ & $2,326 / 2017$ & 582 & 15,132 \\
\hline Barka & \multirow[t]{2}{*}{ Banana } & $2,326 / 2017$ & 582 & 15,132 \\
\hline Salalah & & $752,289 / 2018$ & 188,072 & $4,889,872$ \\
\hline Salalah & $\begin{array}{l}\text { Coconut and } \\
\text { Luban }\end{array}$ & $752,289 / 2018$ & 188,072 & $4,889,872$ \\
\hline
\end{tabular}

Source: (FAO, 2019; MoTO, 2016) 


\section{Discussion}

Oman is rich in many potential sites of tourism, agriculture, and heritage that distinguish it from many neighbouring countries. Most of the tourist areas in Oman are surrounded by agricultural horizons, which can contribute to introducing the concept of agritourism in the country and increasing investments in this sector (Oman Vision 2040, 2020; Sokhalingam et al., 2013). The selected agricultural sites in this study indicated highly potential for applying agritourism. The results showed that Salalah is the top agritourism destination with a predicated annual agritourist for about 188,000 tourists and about US\$5 million of the annual income of each agritourism farm. The other three top agritourism destinations in Oman are Al-Jabal Al-Akhdar with 57,000 agritourists and US\$1.5 m, Bidyyah 42,000 agritourists and US\$1.1 m, and Nizwa 25,000 agritourists and US\$700,000. Enhancement of sustainability in agriculture and farm income can be achieved through adding values to agricultural products and participation of the tourists in farm activities (Table 6) that will contribute to the promotion of many agricultural sites for agritourism.

Oman vision 2040 aimed to increase the \% GDP by 6-9\% through tourism. In addition to that, the contribution of the agricultural sector to the national economy is about US\$ 1.54 billion annually. Therefore, there are opportunities for agritourism to contribute to improving tourism and agricultural sectors by increasing the number of annual agritourists and the farm income. Agriculture and rural development through tourism are targeted to create economic diversification in the country, which makes agritourism an important sector to achieve this diversity. Moreover, the agriculture and tourism sectors simultaneously are expected to contribute significantly to raising the country's economy, creating job opportunities for young people as indicated by the Oman Vision 2040, and reaching food security and agricultural sustainability. This program initiative should be included with capacity building, and technology transfer components as these farms would need new technologies and training for those who involve in the sector.

\section{Conclusions}

Oman is looking to find alternative economic options that are not dependent on oil, such as tourism and agriculture. Many of the tourism destinations in Oman are surrounded by agriculture, and there is a possibility of linking natural tourism sites with the surrounded agricultural areas to introduce the concept of agritourism in the country, increase the investments in this sector and make Oman prominent tourism. Agritourism may improve and raise food security and agricultural sustainability by increasing the productivities of many agricultural products through value addition, which will contribute to the participation of local products in the global markets and improve farmers' livelihood in the country. 


\section{References}

Abdul-Ghani, M. (2006). Hospitality and tourism education in the making: the case of the Sultanate of Oman. Journal of Teaching in Travel \& Tourism, 6(2), 71-87.

Al-Badi, A., Tarhini, A., \& Al-Sawaei, S. (2017). Utilizing social media to encourage domestic tourism in Oman. International Journal of Business and Management, 12(4), 84-94.

Al-Ismaili, A. M., Al-Mezeini, N. K., \& Jayasuriya, H. P. (2017). Controlled environment agriculture in Oman: Facts and mechanization potentials. AMA, Agricultural Mechanization in Asia, Africa and Latin America, 48(2), $75-81$.

Al-Kalbani, M. S., Price, M. F., O'Higgins, T., Ahmed, M., \& Abahussain, A. (2016). Integrated environmental assessment to explore water resources management in Al Jabal Al Akhdar, Sultanate of Oman. Regional Environmental Change, 16(5), 1345-1361.

Al-Kharosi, S. (2017). Economic activities in Oman under Sultan bin Ahmed Al Busaidi (4-4). AlRoya Newspaper. https://alroya.om/post/200280/ (4-4)

Al-Salmi, S. (2018). Handicrafts in Nizwa, Legacy inherited by generations. Al-Watan Newspaper. http://alwatan.com/details/285976

Al-Sheriani, A. (2014). Al Kasfa Hot Spring. Rustaq Online. http://www.alrustaq.net/portal/en/81-rustaqtour/90alkasfahostspring

AlMaimani, J., \& Johari, F. B. (2014). Tourism development plan in Oman. Indicator, 2015, 2016p.

Alqattan, A. A., \& Alhayky, A. (2016). Impact of oil prices on stock markets: evidence from gulf cooperation council (GCC) financial markets. Amity Journal of Finance, 1(1), 1-8.

Anon. (2018). Ain Al Thawara is a destination for Omani tourism. Electronic Qabas. https://alqabas.com/518420/

Anon. (2019). Ain al-Thawara in the state of Nakhl. Ministry of Interior. http://www.alrustaq.net/sbportal/tourism/thowarah-spring-nakhal

Arroyo, C. G., Barbieri, C., \& Rich, S. R. (2013). Defining agritourism: A comparative study of stakeholders' perceptions in Missouri and North Carolina. Tourism Management, 37, 39-47.

Atheer-Omania. (2017). is one of the most important agricultural areas. Know what is characterized by the Salalah Plain and what it produces. Atheer. https://www.atheer.om/archives/444655/

Baumer, M. (1983). Notes on trees and shrubs in arid and semi-arid regions (Vol. 2). Food \& Agriculture Org.

Brief, I. (2010). Sustainable Investment in the Middle East and North Africa.

CBO. (2017).Annual report 2017.

https://cbo.gov.om/sites/assets/Documents/English/Publications/AnnualReports/AnnualReport2017eng.pdf

Djuma, H., Bruggeman, A., Eliades, M., \& Lange, M. A. (2016). Non-conventional water resources research in semi-arid countries of the Middle East. Desalination and Water Treatment, 57(5), 2290-2303.

FAO. (2008). the State of Plant Genetic Resources for Food and Agriculture in Oman. http://www.fao.org/3/i1500e/Oman.pdf

FAO. (2019). FAO Country Profiles: Oman, Food and Agricultural Organization of the United Nations. http://www.fao.org/countryprofiles/index/en/?iso3=OMN

Jayasuriya, H. P. W., Al-Ismaili, A. M., \& Al-Shukaili, T. (2017). Farming Systems in Oman and Mechanization Potentials. Agricultural Mechanization in Asia, Africa, and Latin America, 48(2), 66.

Kitous, A., Saveyn, B., Keramidas, K., Vandyck, T., Santos, L. R. L., \& Wojtowicz, K. (2016). Impact of low oil prices on oil exporting countries. In Joint Research Centre Science for Policy Report, European Commission (Vol. JRC101562, Issue EUR27909 EN). https://doi.org/10.2791/718384

Kumar, M. R., \& Dubey, M. K. (2016). Agri-Tourism as an Alternative Source of Earning Income for Farmers in the State of Maharashtra. 3. 
Alaa A.H. / Agricultural sustainability through agritourism in oman and potentials for adoption

Mizyed, N. R. (2013). Challenges to treated wastewater reuse in arid and semi-arid areas. Environmental Science \& Policy, 25, 186-195.

MOI. (2015). the total area of cultivated land in the Sultanate is 164 thousand feddans in 2014 and production is more than one million tons. Ministry of Information. https://omaninfo.om/option.php?Action=pdf\&ID=1287

MoTO. (2016). Ministry of Tourism Oman. https://omantourism.gov.om/ wps/portal/mot/tourism/oman/home/ministry

Nasser, S. (2017). Oman Attractions. Maedouh. https://mawdoo3.com

Oman Vision 2040. (2020). Vision Document-Oman Vision 2040. Supply Chain Management, 1-8. https://www.2040.om/Oman2040-En.pdf

Omaninfo. (2021). Al- Sharqiyah South-Bidyyah Region. Ministry of Information. https://www.omaninfo.om/mainsections/58

SARADS. (2016). Sustainable Agriculture and Rural Development Strategy towards 2040.

Sokhalingam, C. P., Manimekalai, N., \& Sudhahar, C. (2013). Entrepreneurial approach to tourism development in Oman. International Journal of Management, 4(3), 48-60.

Suhar-Omania. (2017). Al Batinah leads the agricultural sector. Al Shabiba Newspaper. https://www.shabiba.com/article/196431/

Sznajder, M., Przezborska, L., \& Scrimgeour, F. (2009). Agritourism - Google Books. CAB International. https://books.google.com.om/books?id=t5YuIMs7mFQC\&pg=PA212\&lpg=PA212\&dq=agritourism+oman\&so urce $=$ bl\&ots $=$ qzodbJWWGA\&sig=6XlpPuUolud -

2XrrpQeFcH0Nnhw\&hl=en\&sa=X\&ved=0ahUKEwiP0cWOyObYAhWS66QKHW4TDm8Q6AEIMzAC\#v=o nepage $\& \mathrm{q}=$ agritourism oman $\& \mathrm{f}=\mathrm{false}$

UNWTO. (2019). United Nations World Tourism Organization. https://www.e-unwto.org/toc/unwtotfb/current

Zekri, S., Mbaga, M., Fouzai, A., \& Al-Shaqsi, S. (2011). Recreational value of an oasis in Oman. Environmental Management, 48(1), 81-88. 